\title{
Integrated management in coastal lagoons of highly complexity environments: Resilience comparative analysis for three case-studies
}

\author{
S. García-Ayllón \\ Department of Civil Engineering, Technical University of Cartagena, Paseo Alfonso XIII, 52, 30203, Cartagena, Spain
}

\section{A R T I C L E I N F O}

\section{Article history:}

Received 13 March 2016

Received in revised form

15 October 2016

Accepted 15 October 2016

Available online $\mathrm{xxx}$

\section{Keywords:}

Lagoon resilience

GIS indicators

Multidisciplinary diagnosis

Integrated lagoon management

\begin{abstract}
A B S T R A C T
Enclosed coastal seas are usually high environmental value territories that are located, in many cases, in developed countries often subjected to a large catalog of anthropic activities such as tourism, agriculture or industry. These more difficult to manage cases are precisely those that require more complex mechanisms to both diagnose their needs as well as to implement measures that allow the cohabitation between existing activities and the preservation of the natural values of these territories.

This article analyzes the link between the lagoon and such activities from a multidisciplinary approach. This new perspective is raised toward implementing integrated analysis methodologies using indicators that determine global diagnostics capable of being compared from one lagoon to another in different parts of the world. To this end, a comparative study has been developed of three highly complex cases located in three different continents: the Salton Sea in America, the Mar Menor in Europe and the Mar Chica in Africa. Through the implementation of GIS-LiDAR analysis tools, an integrated assessment of the situation and the challenges facing these three lagoons will be set out in order to help solve their current issues. The results will enable to highlight the ability of the lagoons to absorb the impacts of the activities that surround them and guide us to where their future management should be routed.
\end{abstract}

(c) 2016 Elsevier Ltd. All rights reserved.

\section{Introduction}

\subsection{Current issues in coastal management of enclosed lagoons}

Coastal lagoon management is a field highly subscribed to research because of the important natural and ecological values that are usually present in these territories. In this context, there are numerous individual studies worldwide (O'Neill et al., 2015; McFadden and Schernewski, 2014; Bellio and Kingsford, 2013) and some theoretical approaches with a certain vocation to address common problems such as water salinity, turbidity or impacts in protected fauna and flora derived from land transformation due to human industrial activities, coastal urbanization or nitrates contributions from agriculture (Tavares et al., 2015; Casini et al., 2015; Conde et al., 2015 or Newton et al., 2014). However, it is difficult to establish general rules regarding such issues since the specific boundary conditions from each context do not make it possible to implement common diagnoses on different case studies.

Within this field, cases focused on lagoons under the effect of

E-mail address: salgarve@ciccp.es. different anthropic activities with significant impacts that have to cohabit with the correct preservation of environmental values are particularly interesting (Rivera-Guzmán et al., 2014). In this sense, very interesting examples of complex cohabitation with activities such as tourism (Suman et al., 2005; Armaitienè et al., 2007), agriculture (Green-Ruiz and Páez-Osuna, 2003; Santos et al., 2008) or industry (Loureiro et al., 2009; García and Muñoz-Vera, 2015) can easily be found. In this sense, questions like "What is the level of impact of these activities on the lagoon?" and "Is the lagoon able to withstand the current situation?" are normally difficult to answer in these contexts of high economic activity. In most cases it is possible to determine some patterns of behavior, with environmental regulations and the degree of consolidation of these activities often being a differentiating factor of the environments located in developing countries (Kumar et al., 2016) in comparison to the developed countries of Europe or the USA (Acquavita et al., 2015; Dorsey et al., 2013). In order to illustrate this situation, three examples encompassing a wide range of geographic, socioeconomic and environmental settings, resulting in different degrees of severity in the respective lagoons, have been selected. The complex management and difficult cohabitation between human activities and the natural environment in coastal lagoons located on three 
different continents: Africa (Mar Chica), Europe (Mar Menor) and North America (Salton Sea), will be exposed for a further integrated diagnosis.

\subsection{Case study locations}

The Mar Chica, also called Nador lagoon, Sebkha Bou Areg or Rbhar Amzian, is a salty coastal lagoon of $115 \mathrm{~km}^{2}$ located in northern Morocco, at the feet of the city of Nador. It has a maximum depth of $8 \mathrm{~m}$ and is located a few kilometers south of the Spanish colony of Melilla. Semicircular in shape, it is separated from the Mediterranean Sea by two sandy strips: Boukana (10 km long) to the north, and Aljazeera (12.5) south, separated by a $120-\mathrm{m}$-wide mouth, where the Mar Chica connects to the Mediterranean (Fig. 1).

The cities of Nador (inside edge), Beni Ansar (border with the Spanish colony of Melilla) are on its shores to the north and Kariat lies to the south, generating the pressure of 200,000 people living near the coast of the lagoon. Because of its importance for waterbirds, the Mar Chica has been declared a RAMSAR site and has been the subject of several research works (Ruiz et al., 2006; Bocci et al., 2016).

This lagoon has been subjected to various human activities such as agriculture for decades, mainly located to the south on the plain of Bou Areg, there is an agricultural area of $92 \mathrm{~km}^{2}$ reaching the coastal strip of the lagoon. Likewise, since the early twentieth century different urban settlements have existed from the Spanish colonial presence in Morocco, several of them linked to the defunct mining activity in the area. Both impacts are directly connected with the lagoon from the south, the first through the Selouane River and the second through the riverbed of Boussardouri. More recently, development has begun on some tourism activity, mainly focused on the peninsula of the Atalayoun, where some residential complexes, marinas and golf courses have been built (although others have been paralyzed as a result of the international financial crisis). Despite not having traditionally been a territory threatened in environmental values, the major transformations undertaken in the vicinity of the lagoon in recent years have generated various criticisms, which have been reflected in studies on the risks from heavy metals (Maanan et al., 2015) or the bloom of harmful algae (Daoudi et al., 2012).
A second example of a coastal lagoon with some differences and similarities regarding the Mar Chica of Morocco is the Mar Menor in Spain. This salt lake of about $135 \mathrm{~km}^{2}$ located on the southeast of the Spanish Mediterranean coast is a paradigmatic example of environmental resilience, and possibly has one of the most varied catalogs of anthropic effects on a salt lagoon (urban settlements, intensive agriculture, mass tourism, industry, mining, fishing, ports, etc. see Fig. 2). This complex management environment has been inhabited by humans for centuries on its continental coastal strip and in summer suffers the effects of the presence of more than 450,000 people.

The lagoon is separated from the Mediterranean Sea by a $20-\mathrm{km}$ former dune ridge (heavily urbanized since the 1960s; see GarcíaAyllon, 2015), which is connected to its waters through 5 channels called "golas". This configuration gives the environment a unique ecosystem of great natural value, currently protected by numerous European and international regulations (Pérez-Ruzafa et al., 2005; Miralles and García-Ayllón, 2013). This context of complex management to sustain its fragile equilibrium is fundamentally threatened by the contributions of the sediments from the wadis that flow into the lagoon. Within these contributions fed by large basins on the mainland special mention must be made to those coming from intensive farming in the west area of the lagoon, and which have been studied extensively in the literature from the biological perspective (Pérez-Ruzafa et al., 1991, 2000 and 2002; Velasco et al., 2006). The worrisome drift that has occurred since last year, 2015, in the situation of the lagoon waters has caused alarm both in environmental circles and in the tourism sector. This situation has forced authorities to launch an ambitious recovery plan of the lagoon that commits all administrations and private agents. The lagoon has been designated by the European Union for the period 2014-2020 as one of the three objectives of Integrated Territorial Investment authorized in Spain.

A third case with some similarities but larger and farther from the coast is the Salton Sea in North America. It is a salted and endorheic lake in California, southwest United States. The lake is physically in a depression between the mountains of San Jacinto to the East and the Chocolate Mountains to the West. It is located in an arid desert environment, to the north of Imperial Valley and just $10 \mathrm{~km}$ south of the first urban areas linked to the well-known

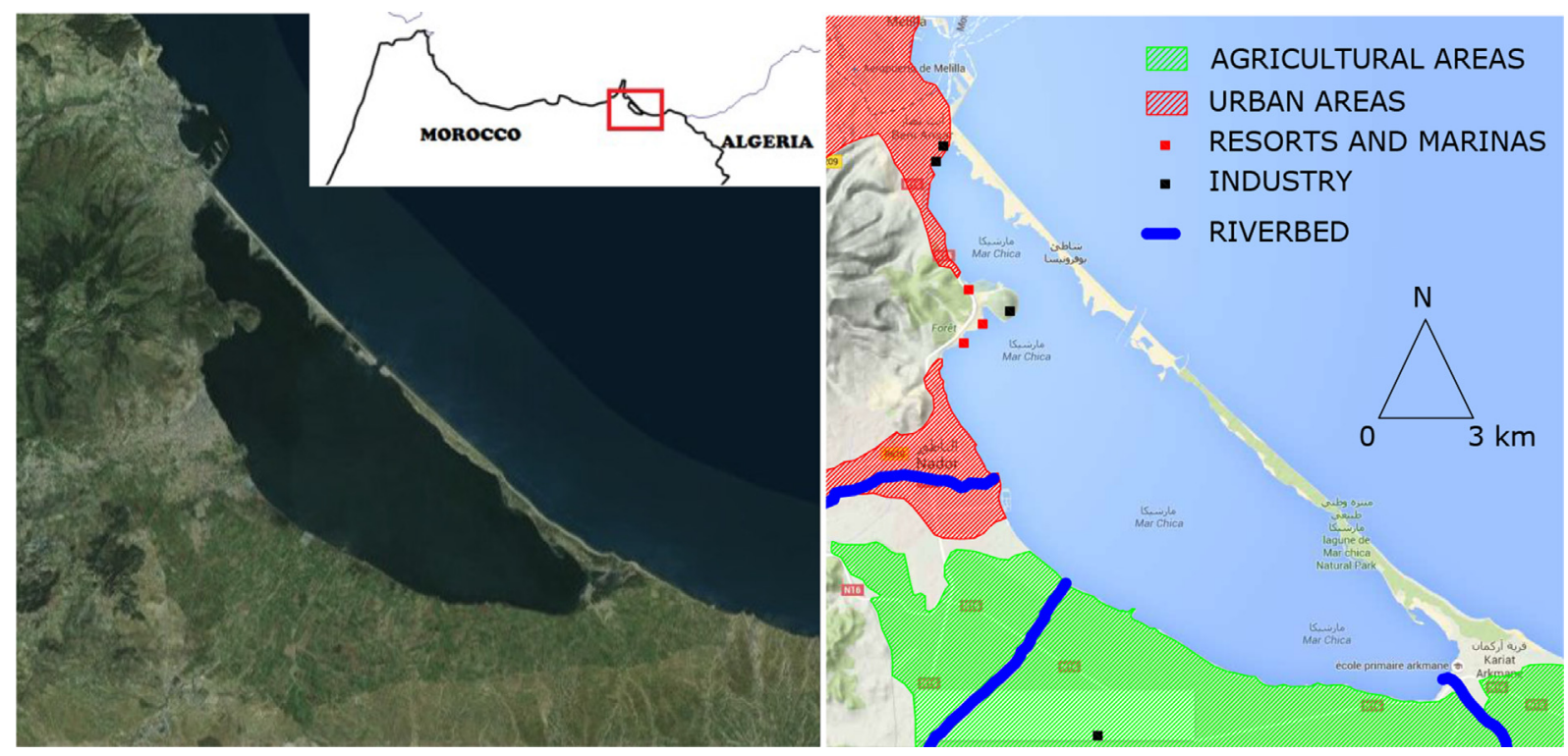

Fig. 1. Mar Chica configuration (left). Activities and uses (right). 


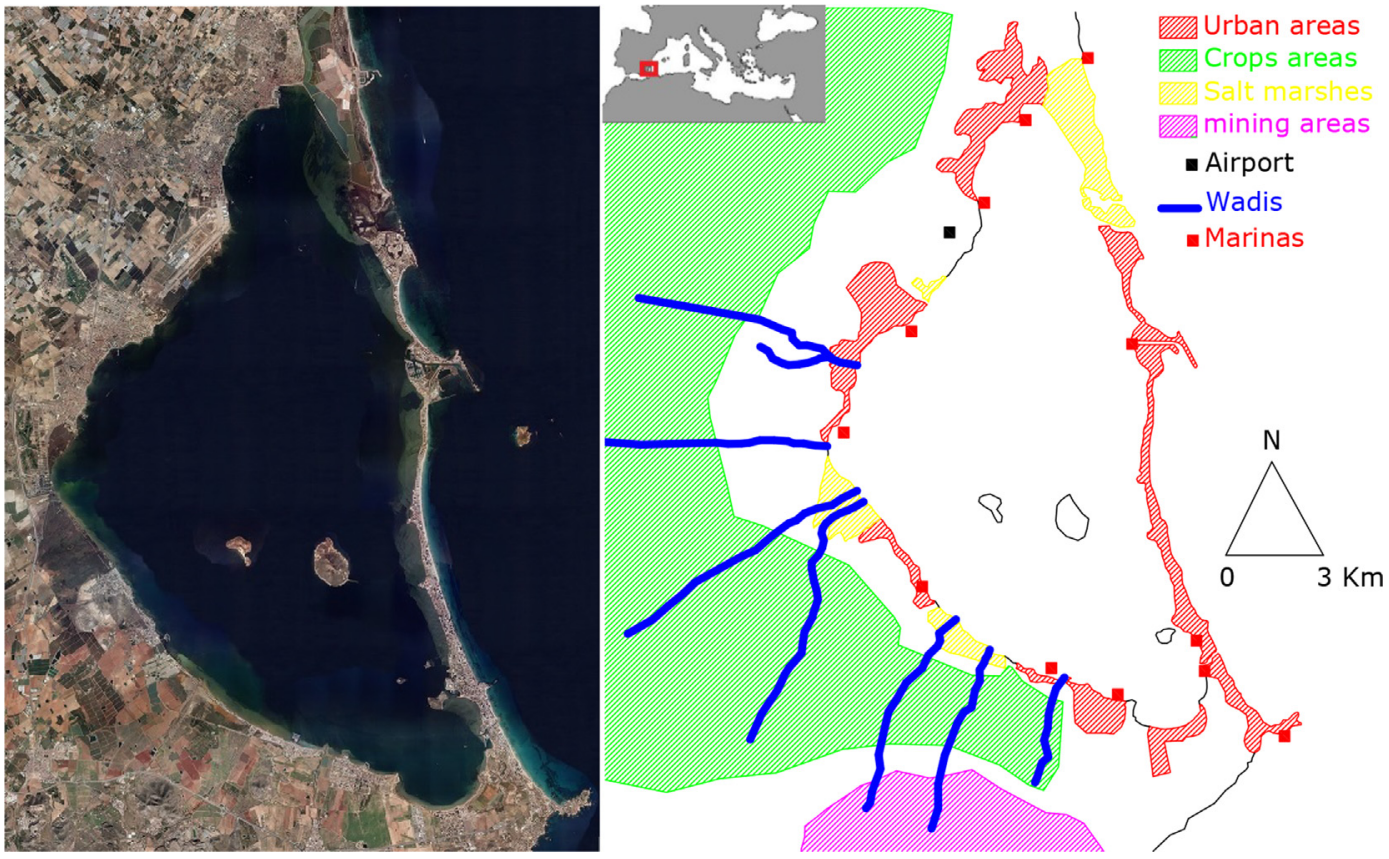

Fig. 2. Mar Menor catalog of anthropic activities around the lagoon.

desert resort city of Palm Springs in Riverside County. The nearest cities to the lagoon (Palms Spring, Cathedral City and Brawley, 100,000 people in total) correspond to models of growth linked to low-density urban sprawl and are placed several kilometers from the lagoon, with the only settlements in the vicinity of its coastal strip being small isolated resorts (some of them now abandoned). Covering $974 \mathrm{~km}^{2}$, Salton Sea is the largest lake in California and is fed by several rivers: the New River, the Whitewater and the Alamo. It measures on average from 24 to $56 \mathrm{~km}$, but its surface area changes according to the water supply, which depends on that used for agriculture, on evaporation and on the annual precipitation.

Unlike the preceding two cases, this is not a salt lake connected directly to an external sea but is $160 \mathrm{~km}$ from the Pacific Ocean and is strongly fed by rivers. Despite this, the lagoon is much deeper than the other two (with mean values of minimum $16 \mathrm{~m}$ and maximum $30 \mathrm{~m}$, in comparison to depths between 3 and $8 \mathrm{~m}$ in the previous cases).

The remarkable history of the lake is well known and has been referenced numerous times in the scientific literature (see for example Setmire, 1979; Setmire et al., 1990; Boyle, 1996). The lake was created by a Colorado River flooding which occurred in 1905 , following a monumental miscalculation in an engineering work. Shortly after a canal had been dug from the Colorado River to irrigate the rich farmland in Imperial Valley, the river overflowed its banks as a result of a series of floods and changed its course. For more than two years, the canal diverted almost all the huge flow of the Colorado River to the Salton depression. Water flooded irrigation canals for several months in the Salton plain, inundating homes and drowning farms and $1000 \mathrm{~km}^{2}$ of desert, thus forming an inland sea.

The management of this lake, which was a touristic picture postcard location in the 1950s, with sandy beaches and thousands of migratory birds, has proved very controversial (Fig. 3). Mainly due to the effects of agricultural activity, its ecosystem is now severely damaged, saturated with salts and pesticides (Glenn et al., 1999). The Salton Sea is naturally salty, but the surrounding land is balanced with salts deposited by an ancient sea (which disappeared millennia ago). Eliminated by the farmers of nearby Imperial Valley to make cropland, salts and the biologic contributions from agriculture have accumulated in the lake, which is now saltier than the Pacific Ocean. Powered by the All-American Canal, Imperial Valley occupies with its crops up to $2000 \mathrm{~km}^{2}$ to the south of the Salton Sea (to which another almost $1000 \mathrm{~km}^{2}$ to the north must then be added, with important urban sprawl developments). Much of this runoff laden with fertilizers and pesticides ends up in the lagoon (Riedel et al., 2002; Sapozhnikova et al., 2004). The lake has some additional contribution of water from local rivers, however with evaporation, pollution accumulates destroying its marine life (Chattopadhyay and Bairagi, 2001).

Authorities, through the Salton Sea land Act (Salton Sea Authority and Bureau of Reclamation, 1998) have planned great works seeking the lake's rehabilitation for 75 years (Cohen et al., 1999). California's Salton Sea Authority and the United States Bureau of Reclamation, leading agencies on the Salton Sea Restoration Project, have enumerated five project goals combining human activities with environmental recovery: to maintain the Salton Sea as a repository for agricultural drainage water; to provide a safe, productive environment for birds and endangered species; restore recreational uses; maintain a sport fishery; and provide opportunities for economic development along the shoreline (Glenn et al., 1999; United States Bureau of Reclamation, 1998). We are thus faced with a context in which the environment to manage provides a more mature situation in which the time to reverse the effects created is significantly longer than the time that motivated its impairment, but in which the maintenance of economic activities is not refused.

\section{Analysis methodology: diagnostic indicators}

The specific diagnosis of these cases is in fact much more complex than as outlined in the previous section. A thorough diagnosis to implement sustainable management in these lagoons subjected to a significant number of impacts must be able to quantitatively evaluate their behavior patterns from a multidisciplinary perspective. In order to analyze these behavior patterns in the three cases studied, various indicators of diagnosis and 


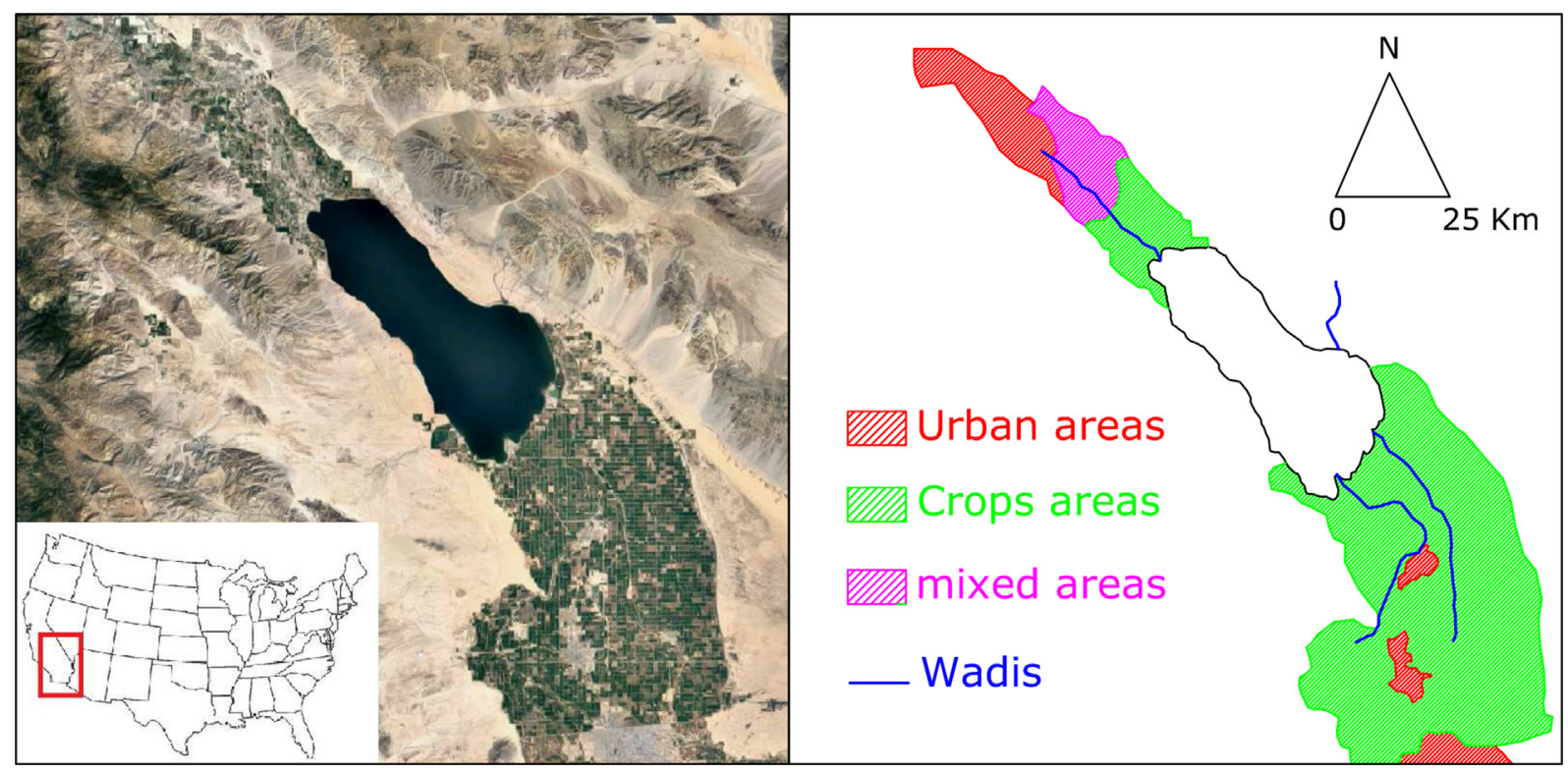

Fig. 3. Salton Sea (left) land use activities (right).

assessment of impacts in the environment will be used. The mere use of indicators is not in itself a novel methodology (see examples in Lu et al., 2012; Mohamed et al., 2014 or Sutherland et al., 2016). It is their implementation through various tools and the interpretation of these phenomena in terms of the management derivations which makes them particularly interesting. To undertake this work two types of indicators have been used: a first family of primary indicators for the analysis of land transformation, and a second family for the diagnosis of issues associated with impacts of these transformations on the environment.

\subsection{Territorial transformation indicators}

The application of the first family of indicators can reveal a common point to all coastal lagoon contexts. The transformation due to human activities in the area surrounding these environments, even if it is in areas located several kilometers from the coastal lagoon, can have a significant impact on it.

In this sense there is no doubt that the urban transformation of the coastal perimeter of an enclosed coastal sea may have an impact on it. However, the development relating to the transformation of natural soil for agricultural, industrial or some other use may have an important reflection that should be taken into account (orographic linkages such as rivers, watersheds or underground runoffs for example). This is the aim of this first family of indicators.

Defining the concept of artificial land transformation is the first step necessary in the implementation of the modalities for the calculation of the impacts on a coastal lagoon. All contexts do not necessarily lead to homogeneous situations due to local facts of different territories and societies. This makes it necessary to establish basic criteria to quantify the changes and thus comparisons between different cases studies of coastal lagoon can be made.

The analysis of the indicators for land transformation and their integration to the core of the systems of territorial planning will determine the areas to be protected and which should be safeguarded as a priority during the management phase. In fact, thanks to the indicators of transformation, and to the constant measuring of each phenomenon over time, it will be possible to understand the dynamics of coastal impacts and therefore to reform territorial and environmental planning instruments. These are the indicators of the land transformation family:

\subsubsection{Indicator 1: index of coast occupation ( $\left.I_{\mathrm{CO}}\right)$}

This index represents the load factor of the first $500 \mathrm{~m}$ of the coastline for each reference area. The definition of urbanized areas according to Yue et al. (2013) corresponds to those essentially agricultural zones or to natural spaces artificially transformed into urban areas (not including agricultural transformations).

Calculation Method: coastal surface of consumed territory in areas not yet urbanized in relation to total coastal surface in the perimeter of the lagoon

Formula : $\mathrm{I}_{\mathrm{CO}}=\mathrm{U}_{\mathrm{A}} / \mathrm{S}_{\mathrm{A}}$

$\mathrm{I}_{\mathrm{CO}}$ : Index of coastal lagoon occupation showing the percentage of land occupied by artificial surfaces within the first $500 \mathrm{~m}$ of coast for each reference area.

$\mathrm{U}_{\mathrm{A}}$ : Urbanized area $\left(\mathrm{Km}^{2}\right.$ occupied by artificial areas).

$\mathrm{S}_{\mathrm{A}}$ : Reference Area $500 \mathrm{~m}$ coast $\left(\mathrm{Km}^{2}\right.$ divisions within a $500-\mathrm{m}$ buffer area developed in parallel to the shore of the lagoon).

\subsubsection{Indicator 2: index of agricultural affection $\left(I_{A A}\right)$}

This index represents the agricultural cultivated area whose superficial and subterranean contributions maintain some kind of physical link with the lagoon. The concept of linkage is given by the GIS model, and must be defined homogeneously in order to admit subsequent comparisons. The methodology is indicative and the user is not obliged to use that analysis line, but must use at least some other justified methods of calculation.

Calculation Method: dimensionless relationship between the presence of agriculture activities and the surface of the lagoon.

Formula : $\mathrm{I}_{\mathrm{AA}}=\mathrm{S}_{\mathrm{A}} / \mathrm{S}_{\mathrm{L}}$ 
$\mathrm{I}_{\mathrm{AA}}$ : Index of agricultural impact showing the percentage of agricultural land linked to the lagoon.

$\mathrm{S}_{\mathrm{A}}$ : Natural soil transformed for agriculture with some kind of linkage to the lagoon.

$\mathrm{S}_{\mathrm{L}}$ : lagoon surface.

\subsubsection{Indicator 3: mix incidence $\left(I_{S}\right)$}

Indication of the contribution of different human activities transforming natural soil not including agriculture (industry, mining, fishing, etc.) to the lagoon. In the methodology these activities must have a (direct or indirect) justified link with the environment studied.

Calculation Method: dimensionless relationship between the presence of activities and the surface of the lagoon. The definition of criteria for measuring the activity has to be implemented in the GIS model so different activities can be added homogeneously. The contribution of each of the activities of the lagoon can be modelled by applying correction coefficients which grant a specific weight justifiably.

Formula : $\mathrm{I}_{\mathrm{s}}=\sum\left[\mathrm{S}_{\mathrm{i}} \cdot \mathrm{c}_{\mathrm{i}}\right] / \mathrm{S}_{\mathrm{L}}$

$\mathrm{S}_{\mathrm{i}}=$ activity i measured.

$\mathrm{c}_{\mathrm{i}}=$ correction coefficient for activity $\mathrm{i}$.

$\mathrm{S}_{\mathrm{L}}=$ lagoon surface area.

\subsubsection{Indicator 4: average annual rate in the increase of territory transformation}

The annual growth rate of land transformation allows us to introduce the variable of time in order to assess the "velocity of transformation". This section is of particular interest in terms of analyzing the relationship between the velocity of consumption of natural soil for human activities and its derivatives in the coastal lagoon.

Calculation Method: growth of territory consumption expressed as a percentage of consumed territory over a specific period. This calculation requires the measurement of used territory from two different dates in order to be able to calculate the annual variation.

Formula : $\mathrm{T}_{\mathrm{i}}=100 * \sum\left[\left(\mathrm{C}_{2}-\mathrm{C}_{1}\right) /\left(\mathrm{a} * \mathrm{C}_{1}\right)\right]$

$\mathrm{T}_{\mathrm{i}}=$ average growth rate.

$\mathrm{C}_{\mathrm{i}}$ : value/measurement of consumed territory on the date $\mathrm{i}(\mathrm{Ha})$. a: correction factor (in case of territories transformed homogenously $\mathrm{a}=1$ ).

\subsection{Indicators of transformation derivatives}

Even though the previous family of indicators provides clear information regarding the real nature of the context an enclosed coastal sea is subjected to, they do not completely identify the level of impact of these activities on the lagoon and its capacity to assume them. In order to implement correct policies to manage a coastal lagoon in a comprehensive way, it is first necessary to be able to diagnose the real situation of the global impact of such activities. This question may be answered by this second family of indicators oriented to the derivatives of the transformation impacts.

The aim of these indicators is not oriented to defining the specific impact of a parameter on the lagoon in a precise manner, as can be found in many sectoral studies in the field of biology, geology, chemistry, coastal dynamics, etc., but rather to implement a comprehensive diagnosis that can be compared from one lagoon to another. A wide-ranging approach for managing these complex territories requires a multidisciplinary assessment, avoiding a sectoral focus on the problems. Knowing the degree of fragmentation of such impacts may help for example to understand specific situations due to the structural modifications in the territory. On the other hand, knowing the capacity of the lagoon to "digest" the current context should help the legislators and decision makers in relation to the urgency of the implementation of restorative and preservation actions. A sustainable cohabitation can thereby be managed between the environmental values of the lagoon and those activities that are essential to humans. In this sense, the indicators of this second family are:

\subsubsection{Indicator 5: Indicator of impact fragmentation (IFI)}

A very important element in order to establish this global diagnosis is to know how the changes affect the environment of the lagoon perimeter. In this sense, the degree of fragmentation of the effects from activities detected may be of great interest.

Calculation Method: it is a dimensionless index that relates the fragmentation of the perimeters of impacts from the anthropic activities in relation to the lagoon's surface area. The sum of this perimeter fragmentation is contrasted with the surface area in order to evaluate the global dispersion of these fragmented conditions. A higher value of the indicator indicates a greater degree of dispersion (Note: it must be emphasized that the term dispersion does not refer to a biological or chemical dispersion of a compound in the lagoon, but the degree of geographic fragmentation of the impacts in order to evaluate its management).

Formula : $I F I=\sum_{i} \frac{L_{i}}{S_{A i}} \times \sqrt{S_{L}}$

$\mathrm{L}_{\mathrm{i}}=$ lagoon boundary affected by anthropic activity in the coastal strip $\mathrm{i}(\mathrm{m})$.

$\mathrm{S}_{\mathrm{Ai}}=$ anthropic activity surface area linked to the lagoon through the coastal strip $\mathrm{i}\left(\mathrm{m}^{2}\right)$.

$\mathrm{S}_{\mathrm{L}}=$ lagoon surface area $\left(\mathrm{m}^{2}\right)$.

\subsubsection{Indicator 6: index of coastal lagoon regeneration (CRI)}

One of the main problems associated with unbalanced trends in coastal lagoon evolution is their inability to regenerate themselves. The relationship between potential exogenous inputs to the lagoon and its natural regeneration capacity is an element to define when finding this trend.

Calculation Method: the evaluation of the regenerative index of the lagoon is directly expressed with the ratio of the number and capacity of imbalance input elements against those elements that recover the natural conditions of the lagoon, taking into account climate impacts. The lower the index the more unsustainable the trend will be.

Formula : $C R I=\sum_{i}\left[\frac{n_{1 i}}{n_{2 i}} \cdot \frac{C_{1 i}}{C_{2 i}}\right]$

$\mathrm{n}_{1 \mathrm{i}}=$ number of open sea connections or restorative channels 
$\mathrm{n}_{2 \mathrm{i}}=$ number of effluents or elements generating anthropogenic impacts on the lagoon

$\mathrm{C}_{1 \mathrm{i}}=$ physical capacity of open sea connections or restorative channels and climate inputs (for example precipitations, to define in the GIS model)

$\mathrm{C}_{2 \mathrm{i}}=$ effluents capacity and climate variations (to define in the GIS model)

\subsubsection{Indicator 7: index of lagoon resilience $\left(I_{R}\right)$}

A critical parameter for planners and decision makers in enclosed coastal sea management is the degree of urgency of the current situation of the lagoon. To address this field it is necessary to know the capacity of the lagoon to respond and to resist the effects of such activities and recover its equilibrium; this would be called the resilience of the lagoon. However, because of its breadth of uses it is advisable to specify the term resilience. According to Holling (1973), resilience describes the persistence of natural systems against changes in ecosystem variables due to natural or anthropogenic causes. In the classical literature two ways of defining resilience can be found: as the time required for an ecosystem to return to an equilibrium or steady-state following a perturbation (Gunderson, 2000); or as the capacity of an ecosystem to absorb disturbance and reorganize while undergoing change so as to still retain essentially the same function, structure, identity and feedbacks (Walker et al., 2004). This second definition is usually termed 'ecological resilience', and assumes the existence of multiple stable states or regimes, which seems more suitable in order to establish an index of lagoon resilience.

Calculation Method: There are several proposals for this by addressing the problem from a sectoral perspective (see for example Folke et al., 2002, 2004). To determine the degree of maturity of the problem from a comprehensive point of view it is proposed to relate the capacities of the lagoon to "digest" the impacts of the activities studied in comparison to its amplitude with the help of the above parameters. A higher value of the dimensionless index indicates greater resilience:

Formula : $I_{R}=\frac{S_{L} \cdot p \cdot C R I}{\sum S_{A I} \cdot I F I \cdot p_{u}}$

$\mathrm{S}_{\mathrm{L}}=$ lagoon surface area $\left(\mathrm{m}^{2}\right)$.

$\mathrm{p}=$ average depth of the lagoon $(\mathrm{m})$.

$\mathrm{CRI}=$ Coastal Regeneration Index.

$\mathrm{S}_{\mathrm{AI}}=$ activities linked to surface areas of the lagoon $\left(\mathrm{m}^{2}\right)$.

IFI = Indicator of Impact Fragmentation.

$\mathrm{p}_{\mathrm{u}}=$ coastal lagoon urbanized perimeter $(\mathrm{m})$.

\subsection{Integrated GIS analysis: conformation of the model}

In order to develop an integrated diagnosis of the three casestudies, a GIS-Lidar analysis must be carried out using the evaluation parameters for each of the coastal lagoons. In this study, it should be noted that we start from three cases with very different boundary conditions, which required the building of a model adapted to all of them in order to later present a comparative analysis.

An aspect to be clearly defined in the GIS model implemented is the concept of linkage, as commented in the previous sections. Looking at the measurement of the affected surface areas, especially regarding the agricultural areas, the existing literature has been taken into account in all three cases (seen above in Section 1). In areas where no information was available, or existing information was contradictory depending on the consulted versions, LiDAR criteria developed in the IMIDA Institute of the Region of Murcia (IDERM, 2014) have been used (good similar examples can be found in Ellis et al., 2016; Tesfamichael \& Beech, 2016 or Cao et al., 2016). The surface areas finally analyzed can be observed in the summary table of the following section.

In the case of the weighting coefficients of the parameter $I_{S}$, they have been set qualitatively depending on what was concluded for each of the areas in the literature consulted. It is therefore inevitable to assume some degree of subjectivity in the valuation, preventing a perfect homogeneity in the comparison for this variable, although it is estimated that the assessment made may provide an acceptable approximation. In this sense, coefficients have been used that correct the unit value by just $10 \%$ (with the range being 0.9-1.1, situation justified in the absence of distorting activities that would generate a very different impact on any of the three cases).

For the formulation of the CRI index only two concepts were taken into account in order to shape the model in a simplified manner: water direct arrivals and climate impact (sea connections and average rainfall observed on the water surface for $C_{1}$ vs. water contributions through wadis and the estimated evaporation in the lagoon in $\mathrm{C}_{2}$ ).

\section{Results}

Having implemented a GIS-LiDAR model according to the mentioned criteria, the summary of the results for the three case studies is as follows (Table 1):

Table 1

Summary results of different parameters for Mar Chica, Mar Menor and Salton Sea.

\begin{tabular}{llll}
\hline & Mar Chica & Mar Menor & Salton Sea \\
\hline Area analyzed $\left(\mathrm{km}^{2}\right)$ & 197.6 & 1024.6 & 2718.7 \\
I $_{\text {CO: Index of coast occupation }}$ & 0.41 & 0.67 & 0.09 \\
I $_{\mathrm{AA}}$ : Index of agricultural affection & 0.47 & 4.67 & 2.27 \\
$\mathrm{I}_{\mathrm{S}}$ : Mix incidence & 0.11 & 0.19 & 0.02 \\
$\mathrm{~T}_{\text {2000-2015: Territory transformation }}$ & 0.21 & 0.07 & 0.05 \\
$\quad$ between 2000 and 2015 & & & \\
IFI: Indicator of impact fragmentation & 0.13 & 0.12 & $<0.01$ \\
CRI: Index of coastal lagoon & 0.67 & 0.61 & 0.07 \\
$\quad$ regeneration & & & \\
$\mathrm{I}_{\mathrm{R}}$ : Index of Lagoon resilience & 0.41 & 0.63 & 0.29 \\
\hline
\end{tabular}

A first analysis shows major differences between the affected surface areas of the lagoons. Although in total value the Salton Sea clearly has the largest area, it is the Mar Menor which has a higher relative proportion (it must be taken into account that although the Salton Sea has a higher area of influence linked to the lagoon (2718 $\mathrm{km} 2$ vs 1024), the Mar Menor has a higher relative proportion of such influence $(1024 / 135=758 \%$ is higher than $974 / 2718=279 \%)$. This rate can give us an idea of the weight each lagoon has in the territory surrounding it.). This concept can be checked with the values of $\mathrm{I}_{\mathrm{AA}}, \mathrm{I}_{\mathrm{CO}}$ and $\mathrm{I}_{\mathrm{S}}$ where different behaviors are observed.

First, in relation to the urban impact it should be noted that the index of coastal urbanization of the Mar Chica (0.41) and the Mar Menor (0.67) are both much higher than that of the Salton Sea (its impact on the lagoon is rather residual). Urbanized areas in these settings correspond to traditional urban settlements with tourist developments of second homes, whose consolidation is very low in the case of the Salton Sea. A very different situation is observed in the index of agricultural impact, in which (despite the aforementioned superiority in absolute numbers of the Salton Sea due to its large surface area) the value of the $\mathrm{I}_{\mathrm{AA}}$ index is much greater for the Mar Menor (4.67). In this sense, despite the existence of impacts in 
this field for the three lagoons, the significant difference between these two in comparison to the Mar Chica (0.47) should be noted. The index for mixed use however, takes us back to the initial situation in which the Mar Menor, because of its varied impacts catalog (industrial, mining, port and even an airport), has a high value and the Salton Sea only presents a residual effect.

In contrast to all these analyses we have the trend study of land transformation in the three lagoons over the past fifteen years. In this case, the Mar Chica has considerably higher values (0.21) than the other two (0.07 and 0.05$)$. In this case, important land transformation processes are appreciated within the area of linkage to the lagoon, especially in relation with the $\mathrm{I}_{\mathrm{CO}}$ index. In the other two, only minor processes are appreciated, especially in the agricultural sector $\left(\mathrm{I}_{\mathrm{AA}}\right)$ and the non-coastal urban sprawl ( $\mathrm{I}_{\mathrm{S}}$ ), with the concept of linkage even being questionable in some of them (essentially new crops and tourist resorts) because of the distance to the lagoon (>20 km).

With the parameters obtained, the integrated diagnosis has been implemented. Regarding the degree of fragmentation impacts it should be noted that the issues detected are fairly concentrated in all three cases, but with an extreme absence of dispersion $(<0.01)$ corresponding to the case of the Salton Sea, due to its mainly agricultural problems.

A very different situation is found in the assessment of the regenerative capacity of the lagoon. Both the Mar Menor (0.61) and the Mar Chica (0.67) have an important natural connection and a climate that allows them to better adapt to the impacts of human activities. The Salton Sea meanwhile lacks favorable boundary conditions in this regard (0.07), with its disassociation from the Pacific Ocean being a serious handicap to implement environmental restoration processes. A similar situation albeit with important numerical nuances can be found in the $I_{R}$ index, where the values of the Mar Menor (0.63) and the Mar Chica (0.41) are higher than that of the Salton Sea (0.29).

\section{Discussion}

The results obtained are rather revealing in some fields. In this sense a wraparound approach to numerical values confirms a situation of greater impact on the Mar Menor and the Salton Sea (more diffuse in the former and more concentrated in agriculture in the latter) than in the Mar Chica. Nevertheless, in some sections it is necessary to raise an interpretative approach to them. Thus, certain values should be measured in a combined way and approached with a comparative perspective inasmuch as the indicators are constrained by different boundary conditions that must be taken into account.

First, it is necessary to consider the current impact of environmental and territorial regulations of each country, since transformation processes are highly conditioned by their nature. The case of environments that could be seen as similar for the geographic and climatic proximity (despite being located on different continents) is given by the Mar Menor and the Mar Chica which have been under very different boundary conditions in recent years as a result of environmental regulation. Both have had interaction with nearby towns for many decades, but while in the Mar Chica an important process of transformation has been experienced in the last decade along its coastal perimeter (slowed in recent years by the effects of the economic crisis), the European environmental regulation of the region prevents major changes in the immediate vicinity of the Mar Menor (similar case studies context in Europe can be found in Mateus et al., 2016 or Povilanskas et al., 2014). This more dynamic transformation pattern in the Mar Chica indicates that although the latter situation is much less mature (mainly due to lower technological modernization of agriculture, which does not reach the category of intensive), possibly the comparative diagnosis performed is susceptible to evolve for this lagoon in the coming years if the current transformation inertia persists, which recommends carry in-depth studies to correctly channel it.

In these same years it can be seen how the impact of human activities is apparently more pronounced in the Mar Menor than in the Mar Chica, despite the increased activity in the latter (mainly linked to construction and tourism). This paradoxical situation is related to the concept of linking between activities and the lagoon. The Mar Menor is highly protected by the Natura 2000 European network with several regulations of environmental protection disqualifying almost any new action on it (Blicharska et al., 2016). Nevertheless, the Mar Menor is situated at the end of a large watershed delimited by a group of mountain ranges surrounding the area called the Campo de Cartagena, an extensive plain of around $1440 \mathrm{~km}^{2}$. Freshwater inputs into the lagoon are restricted to the six ephemeral watercourses called 'wadis'. These wide, shallow gullies are generally inactive, but can carry great amounts of water and sediment during the traditional Mediterranean flood episodes of autumn. The torrential nature of the supplies is aggravated by the impermeable soils and scarce vegetation cover of the watershed areas, going directly to the Mar Menor.

The Albujon watershed for example, draining an area of $441 \mathrm{~km}^{2}$ (more than three times larger than the Mar Menor itself), covers about one third of the total surface area of the Campo de Cartagena (Velasco et al., 2006). This territory, in contrast to the Mar Menor, has no specific environmental protection since it does not have special natural values (see Fig. 4). In this context, the hydrological transfer between the Tagus and Segura rivers has transformed thousands of hectares into croplands over the past thirty years, leading the Campo de Cartagena to become a strategic economic asset for the whole region, which is now called the "Orchard of Europe", involving a major source of nitrates to the lagoon. In this way, it can be seen how the absence of an integrated diagnosis of the issues taking into account the different stakeholders has prevented decision-makers from developing a proper approach to the solution, with much of the problem often being many kilometers away from the lagoon itself (similar issues in different contexts can be found all over the world for coastal lagoons, La Jeunesse et al., 2015; Ozturk and Sesli, 2015; Rivera-Guzmán et al., 2014).

On the other hand, it is also important to look at the historical idiosyncrasy of the lagoon uses in order to establish an integrated diagnostic of its management (Chapman, 2012). In this sense, it is important to consider variables that because of their nature may intrinsically be a source of heterogeneity. In this regard, for the development of the GIS model the different links of the three casestudies with the sea were taken into account (very present in the Mar Menor and the Mar Chica and almost nonexistent in the Salton Sea). Likewise, in order to perform a homogeneous comparative analysis this has been noted into the configuration of the variables that could be susceptible to be influenced by the phenomenon of "size effect" (it must be recalled that the Salton Sea is seven times larger than the Mar Menor and the Mar Chica).

Examples like the Salton Sea and the Mar Menor could apparently have many points in common for their management due to the issues concerning the agricultural activities and their climate and socioeconomic location in countries that make them potential objectives for tourism and residential development. Nevertheless, we are facing very different situations. The Mar Menor is a natural lagoon which for centuries has served to support urban settlements, nautical activities, fishing or the salt and mining industry, with a strong link to the Mediterranean Sea (like others famous examples such as the Thau lagoon in France or the Venetian lagoon in Italy). By contrast, the Salton Sea is a salt lake created artificially 


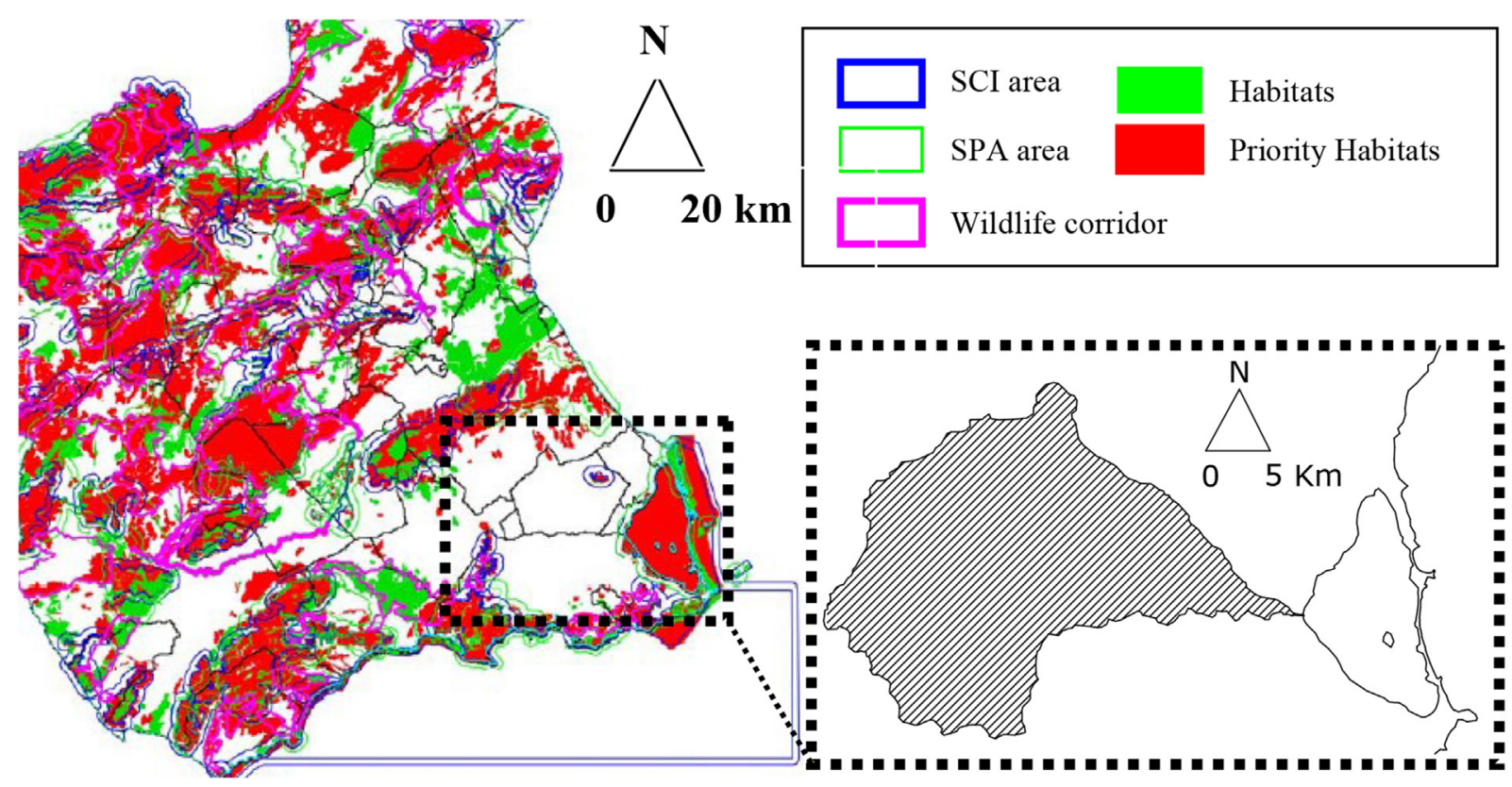

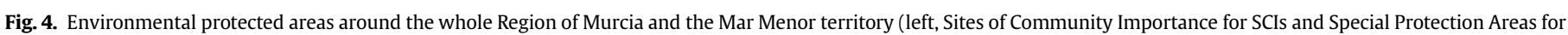
SPAs) and detail of the Albujon watershed (right, watershed plot in the striped area).

barely a hundred years ago (like similar cases in the world linked to dams construction such as Kariba, Volta and Nasser in Africa, or Guri and Minnewanka in America, albeit unintentionally created), with living and working conditions whose resilience has not been proved naturally by the environment (thus its natural permanence is not even guaranteed in the absence of impacts derived from human activities).

This circumstance in conjunction with the low value obtained for the IFI $(<0.01$, as a consequence of the weight of agricultural activity in the whole of impacts, and the distribution of its affection to the lagoon in a concentrated manner on two points in the north and south of the territory) in theory facilitates the management of solutions for the Salton Sea, in comparison to the other two (whose configuration is more complex in presentation). Nevertheless, this does not provide us with clues about the extent of the problem for any of them.

This extent may be estimated through the index of resilience for each case studied. In this regard, we can conclude that among a greater capacity to overcome the effects posed by the different human activities taking place in its environment. The Mar Chica presents an acceptable index (0.41), although its current affected levels are lower while the growth rate of its impacts by land transformation is greater. Meanwhile the Salton Sea presents a much poorer value $(0.29)$, despite the significant effect that its high volume implies (both in surface area as well as the depth of the lagoon). This result confirms a very worrying situation from the point of view of the management of a process that may prove irreversible in these conditions, unless very important investments are carried out to revert this situation (Glenn et al., 1999).

Uniting all these postulates together, if the overall situation of each of the three cases were illustrated in a life cycle curve, as happens in other scientific fields linked to management (Butler, 1980; Catry and Chevalier, 1974; Cooper and Zhu, 2016; Kalbar et al., 2016), a graph showing the "maturity" of the comparative situation like the following could be obtained (Fig. 5):

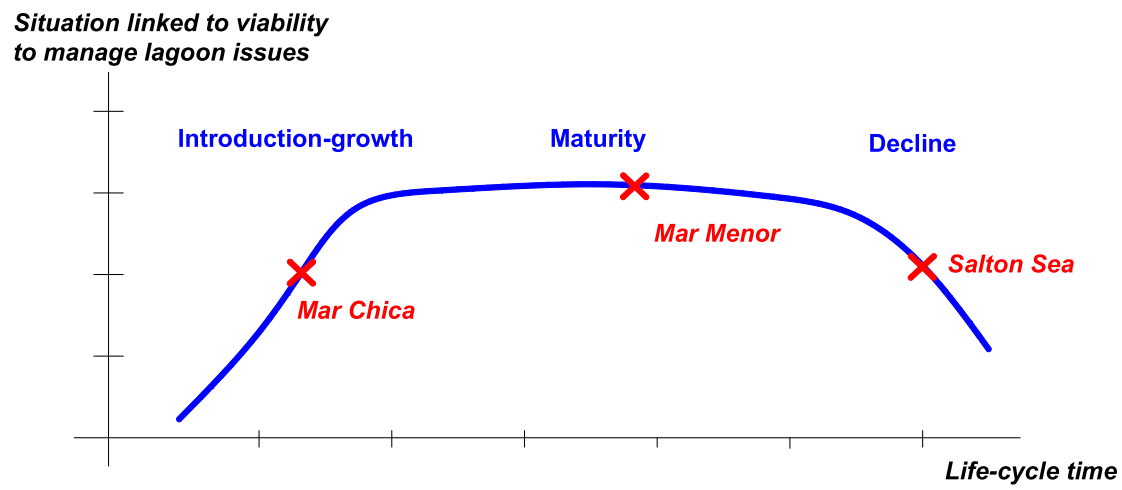

Fig. 5. Simulation of hypothetical lifecycle curve for the management of problems in a coastal lagoon.

the three cases, the Mar Menor (0.63) is (despite its dangerous current situation submitted to important impacts) the one that has
Based on this, the main results of the study can be summarized in three severity levels of the lagoons. First, corresponding to the 
Mar Chica level, in which, although the situation is far from being irreversible, we must consider the current accelerated transformation inertia as an important risk factor. A second level is that of the Mar Menor, where despite being in a more advanced anthropization process and closer to a turning point, its great capacity for regeneration as a result of its high resilience observed must be taken into account. Finally, there is the situation of Salton Sea: in this case all the red lines have been largely exceeded, and thus the reversal of the process is currently, as shown by the indices analyzed, very complex.

There is no reason for these three situations to be definitive. In this sense, a very interesting field to address in future studies to complete the dynamic evolution of the behavior patterns of these three lagoons (and thus verify the validity of the diagnosis carried out) would be for example to contrast the current values of the various indexes presented with their counterparts in a few years' time.

\section{Conclusions}

This work has addressed the complex problem of managing coastal lagoons located in complex environments from a comprehensive approach. For this objective, an innovative methodology has been applied to three different case studies proposing a comparative diagnosis.

The methodology presented allows us to develop GIS-LiDAR tools for the quantitative integrated analysis of the impacts, effects and threats of human activities in coastal lagoon environments. The traditional heterogeneity of these phenomena complicates the assessment of issues in order to implement efficient management in those complex territories of high environmental value, restricting the possible diagnoses to sectoral studies focused on specific scientific fields or simple qualitative assessments.

Based on the results obtained, a distinct diagnosis is shown in each case under study, showing three different levels of severity. The most worrying level of severity can be observed in the Salton Sea where global issues deal with a primarily agricultural component, concentrated configuration, and very high degree of human activities-lagoon interaction. The situation can be characterized as critical, since the capacity for the process that has caused the damage to be reverted by itself is very limited. This conjuncture describes a mature situation for management, which involves large investments and requires great management performances in order to try to reverse the process to its previous state.

The case of the Mar Menor can be categorized as a second level of severity, very serious due fundamentally to the impact of intensive agriculture, which could mean that the situation may be approaching a turning point in its natural balance. Nevertheless, its enormous strength and ability to overcome human activities clearly distinguish it from the situation of the Salton Sea. It must also be taken into account that it has surely the most complex configuration of the three cases as a consequence of being subjected to a set of very heterogeneous and fragmented conditions, making it more difficult to manage and implement restoration solutions. This situation requires especially focusing the management process of the lagoon in an integrated manner which directly involves all the stakeholders concerned.

The Mar Chica appears on the opposite side of the scale with the lowest level of severity. Nevertheless, this does not mean that its diagnosis is far more favorable. The Mar Chica presents some similar configurations to the Mar Menor regarding the fragmentation of impacts, but its intrinsic resilience is poorer. This situation in the current context of growth for the land transformation parameters analyzed warns of problems that this lagoon will surely be submitted to in the close future, which recommends in this case carrying out in-depth studies to correct or properly channel this inertia.

\section{Appendix A. Supplementary data}

Supplementary data related to this article can be found at http:// dx.doi.org/10.1016/j.ocecoaman.2016.10.007.

\section{References}

Acquavita, A., Aleffi, I.F., Benci, C., Bettoso, N., Crevatin, E., Milani, L., Tamberlich, F. Toniatti, L., Barbieri, P., Licen, S., Mattassi, G., 2015. Annual characterization of the nutrients and trophic state in a Mediterranean coastal lagoon: the Marano and Grado Lagoon (Northern Adriatic Sea). Reg. Stud. Mar. Sci. 2, 132-144. http://dx.doi.org/10.1016/j.rsma.2015.08.017.

Armaitienè, A., Boldyrev, V.L., Povilanskas, R., Taminskas, J., 2007. Integrated shoreline management and tourism development on the cross-border World Heritage Site: a case study from the Curonian spit (Lithuania/Russia). J. Coast. Conserv. 11 (1), 13-22. http://dx.doi.org/10.1007/s11852-007-0001-8.

Bellio, M., Kingsford, R.T., 2013. Alteration of wetland hydrology in coastal lagoons: implications for shorebird conservation and wetland restoration at a Ramsar site in Sri Lanka. Biol. Conserv. 167, 57-68. http://dx.doi.org/10.1016/j.biocon. 2013.07.013.

Bocci, M., Brigolin, D., Pranovi, F., Najih, M., Nachite, D., Pastres, R., 2016. An Ecosystem Approach for understanding status and changes of Nador lagoon (Morocco): application for of food web models and ecosystem indices. Estuar. Coast. Shelf Sci. 171, 133-143. http://dx.doi.org/10.1016/j.ecss.2016.01.004.

Blicharska, M., Orlikowska, E., Roberge, J.M., Grodzinska-Jurczak, M., 2016. Contribution of social science to large scale biodiversity conservation: a review of research about the Natura 2000 network. Biol. Conserv. 199, 110-122. http://dx. doi.org/10.1016/j.biocon.2016.05.007.

Boyle, R.H., 1996. Life, or death, for the Salton Sea (the plight of California's otherworldly sea). Smithsonian 27, 86-97.

Butler, R.W., 1980. The concept of the tourist area life-cycle of evolution: implications for management of resources. Can. Geogr. 24 (1), 5-12. http://doi.org/10. 1111/j.1541-0064.1980.tb00970.x.

Cao, L., Coops, N., Innes, J.L., Dai, J., Ruan, H., She, G., 2016. Tree species classification in subtropical forests using small-footprint full-waveform LiDAR data. Int. J. Appl. Earth Obs. 49, 39-51. http://dx.doi.org/10.1016/j.jag.2016.01.007.

Casini, M., Mocenni, C., Paoletti, S., Pranzo, M., 2015. Decision support system development for integrated management of European coastal lagoons. Environ. Modell. Softw. 64, 47-57. http://dx.doi.org/10.1016/j.envsoft.2014.11.008.

Catry, B., Chevalier, M., 1974. Market share strategy and the product life cycle. J. Mark. 38 (4), 29-34. http://dx.doi.org/10.2307/1250388.

Chapman, P., 2012. Management of coastal lagoons under climate change. Estuar. Coast. Shelf Sci. 110, 32-35. http://dx.doi.org/10.1016/j.ecss.2012.01.010.

Chattopadhyay, J., Bairagi, N., 2001. Pelicans at risk in Salton sea - an ecoepidemiological model. Ecol. Model. 136, 103-112. http://dx.doi.org/10.1016/ S0304-3800(00)00350-1.

Cohen, M.J., Morrison, J., Glenn, E., 1999. Haven or Hazard: the Ecology and Future of the Salton Sea. Pacific Institute, Oakland, CA.

Cooper, R., Zhu, G., 2016. Household finance over the life-cycle: what does education contribute? Rev. Econ. Dyn. 20, 63-89. http://dx.doi.org/10.1016/j.red.2015. 12.001 .

Conde, D., Vitancurt, J., Rodríguez-Gallego, L., de Álava, D., Verrastro, N., Chreties, C., Solari, S., Teixeira, L., Lagos, X., Piñeiro, G., Seijo, L., Caymaris, H., Panario, D. 2015. Solutions for sustainable coastal lagoon management: from conflict to the implementation of a consensual decision tree for artificial opening. Coast. Zones 13, 217-250.

Daoudi, N., Serve, L., Rharbi, N., El Madani, F., Vouvé, F., 2012. Phytoplankton distribution in the Nador lagoon (Morocco) and possible risks for harmful algal blooms. Transit. Waters Bull. 6, 4-19. http://dx.doi.org/10.1285/ i1825229Xv6n1p4.

Dorsey, J., Carmona-Galindo, V.D., Leary, C., Huh, J., Valdez, J., 2013. An assessment of fecal indicator and other bacteria from an urbanized coastal lagoon in the City of Los Angeles, California, USA. Environ. Monit. Assess. 185 (3), 2647-2669. http://dx.doi.org/10.1007/s10661-012-2737-3.

Ellis, P., Griscom, B., Walker, W., Gonçalves, F., Cormier, T., 2016. Mapping selective logging impacts in Borneo with GPS and airborne LiDAR. For. Ecol. Manag. 365, 184-196. http://dx.doi.org/10.1016/j.foreco.2016.01.020.

Folke, C., Carpenter, S., Elmqvist, T., Gunderson, L., Holling, C.S., Walker, B., 2002. Resilience and sustainable development: building adaptive capacity in a world of transformations. Ambio 31 (5), 437-440. http://dx.doi.org/10.1579/00447447-31.5.437.

Folke, C., Carpenter, S., Walker, B., Scheffer, M., Elmqvist, T., Gunderson, L., Holling, C.S., 2004. Regime shifts, resilience, and biodiversity in ecosystem management. Annu. Rev. Ecol. Evol. Syst. 35, 557-581. http://dx.doi.org/10. 1146/annurev.ecolsys.35.021103.105711.

García-Ayllon, S., 2015. La Manga case study: consequences from short-term urban planning in a tourism mass destiny of the Spanish Mediterranean coast. Cities 
43, 141-151. http://dx.doi.org/10.1016/j.cities.2014.12.001.

García, G., Muñoz-Vera, A., 2015. Characterization and evolution of the sediments of a Mediterranean coastal lagoon located next to a former mining area. Mar. Pollut. Bull. 100 (1), 249-263. http://dx.doi.org/10.1016/j.marpolbul.2015.08. 042.

Glenn, E.P., Cohen, M.J., Morrison, J.I., Valdés-Casillas, C., Fitzsimmons, K., 1999 Science and policy dilemmas in the management of agricultural waste waters: the case of the Salton Sea, CA, USA. Environ. Sci. Policy 2, 413-423. http://dx. doi.org/10.1016/S1462-9011(99)00037-4.

Green-Ruiz, C., Páez-Osuna, F., 2003. Heavy metal distribution in surface sediments from a subtropical coastal lagoon system associated with an agricultural basin. B Environ. Contam. Toxicol. 71 (1), 52-59. http://dx.doi.org/10.1007/s00128003-0130-1.

Gunderson, L.H., 2000. Ecological resilience - in theory and application. Annu. Rev. Ecol. Syst. 31, 425-439. http://dx.doi.org/10.1146/annurev.ecolsys.31.1.425.

Holling, C.S., 1973. Resilience and stability of ecological systems. Annu. Rev. Ecol. Syst. 4,1-23.

IDERM, 2014. Metadata Catalogue of IDERM. Imida Institute of the Region of Murcia. http://iderm.imida.es/iderm/index.htm.

Kalbar, P., Karmakar, S., Asolekar, S.R., 2016. Life cycle-based decision support tool for selection of wastewater treatment alternatives. J. Clean. Prod. 117, 64-72. http://dx.doi.org/10.1016/j.jclepro.2016.01.036.

Kumar, A., Equeenuddin, Sk Md, Mishra, D.R., Acharya, B.C., 2016. Remote monitoring of sediment dynamics in a coastal lagoon: long-term spatio-temporal variability of suspended sediment in Chilika. Estuar. Coast. Shelf Sci. 170, 155-172. http://dx.doi.org/10.1016/j.ecss.2016.01.018.

La Jeunesse, I., Cirelli, C., Sellami, H., Aubin, D., Deidda, R., Baghdadi, N., 2015. Is the governance of the Thau coastal lagoon ready to face climate change impacts? Ocean. Coast. Manag. 118, 234-246. http://dx.doi.org/10.1016/j.ocecoaman. 2015.05.014.

Loureiro, D., Fernandez, M., Herms, F., Lacerda, F., 2009. Heavy metal inputs evolution to an urban hypertrophic coastal lagoon, rodrigo de freitas lagoon, rio de Janeiro, Brazil. Environ. Monit. Assess. 159, 577. http://dx.doi.org/10.1007/ s10661-008-0652-4.

Lu, C.Y., Gu, W., Hua, A., Dai, Wei, H.Y., 2012. Assessing habitat suitability based on geographic information system (GIS) and fuzzy: a case study of Schisandra sphenanthera Rehd. et Wils. in Qinling Mountains, China. Ecol. Modell 242, 105-115. http://dx.doi.org/10.1016/j.ecolmodel.2012.06.002.

Maanan, M., Saddik, M., Maanan, M., Chaibi, M., Assobhei, O., Zourarah, B., 2015. Environmental and ecological risk assessment of heavy metals in sediments of Nador lagoon, Morocco. Ecol. Indic. 48, 616-626. http://dx.doi.org/10.1016/j. ecolind.2014.09.034.

Mateus, M., Almeida, D., Simonson, W., Felgueiras, M., Banza, P., Batty, L., 2016. Conflictive uses of coastal areas: a case study in a southern European coastal lagoon (Ria de Alvor, Portugal). Ocean. Coast. Manag. 132, 90-100. http://dx.doi. org/10.1016/j.ocecoaman.2016.08.016.

McFadden, L., Schernewski, G., 2014. Critical reflections on a systems approach application in practice: a Baltic lagoon case study. Reg. Environ. Change 14 (6), 2115-2126. http://dx.doi.org/10.1007/s10113-012-0337-y.

Miralles, J.L., García-Ayllón, S., 2013. The urban metamorphosis of La Manga and the "mediterraneanisation" process of the Mar Menor (Spain). T Ecol. Environ. 169, 53-64. http://dx.doi.org/10.2495/CP130051.

Mohamed, E.S., Saleh, A.M., Belal, A.A., 2014. Sustainability indicators for agricultural land use based on GIS spatial modelling in North of Sinai-Egypt. Egypt. J. Remote Sens. Space Sci. 17, 1-15. http://dx.doi.org/10.1016/j.ejrs.2014.05.001.

Newton, A., Icely, J., Cristina, S., Brito, A., Cardoso, A.C., Colijn, F., Dalla Riva, S., Gertz, F., Hansen, J.W., Holmer, M., Ivanova, K., Leppäkoski, E., Canu, D.M., Mocenni, C., Mudge, S., Murray, N., Pejrup, M., Razinkovas, A., Reizopoulou, S. Pérez-Ruzafa, A., Schernewski, G., Schubert, H., Carr, L., Solidoro, C., Viaroli, P., Zaldivar, J.M., 2014. An overview of ecological status, vulnerability and future perspectives of European large shallow, semi-enclosed coastal systems, lagoons and transitional waters. Estuar. Coast. Shelf Sci. 140 (1), 95-122. http://dx.doi. org/10.1016/j.ecss.2013.05.023.

O'Neill, K., Schreider, M., McArthur, L., Schreider, S., 2015. Changes in the water quality characteristics during a macroalgal bloom in a coastal lagoon. Ocean. Coast. Manag. 118, 32-36. http://dx.doi.org/10.1016/j.ocecoaman.2015.04.020.

Ozturk, D., Sesli, F.A., 2015. Shoreline change analysis of the Kizilirmak Lagoon series. Ocean. Coast. Manag. 118, 290-308. http://dx.doi.org/10.1016/j. ocecoaman.2015.03.009.

Pérez-Ruzafa, A., Marcos, C., Ros, J.D., 1991. Environmental and biological changes related to recent human activities in the Mar Menor (SE of Spain). Mar. Pollut.
Bull. 23, 747-751. http://dx.doi.org/10.1016/0025-326X(91)90774-M.

Pérez-Ruzafa, A., Navarro, S., Barba, A., Marcos, C., Cámara, M.A., Salas, F., 2000. Presence of pesticides through trophic compartments of the food web in the Mar Menor lagoon (SE Spain). Mar. Pollut. Bull. 40, 140-151. http://dx.doi.org/ 10.1016/S0025-326X(99)00193-9.

Pérez-Ruzafa, A., Gilabert, J., Gutiérrez, J.M., Fernández, A.I., Marcos, C., Sabah, S., 2002. Evidence of a planktonic food web response to changes in nutrient input dynamics in the Mar Menor coastal lagoon, Spain. Hydrobiologia 475/476, 359-369. http://dx.doi.org/10.1007/978-94-017-2464-7-26.

Pérez-Ruzafa, A., Fernández, A.I., Marcos, C., Gilabert, J., Quispe, J.I., GarcíaCharton, J.A., 2005. Spatial and temporal variations of hydrological conditions, nutrients and chlorophyll a in a Mediterranean coastal lagoon (Mar Menor Spain). Hydrobiologia 550, 11-27. http://dx.doi.org/10.1007/s10750-005-43562.

Povilanskas, R., Razinkovas-Baziukas, A., Jurkus, E., 2014. Integrated environmenta management of transboundary transitional waters: curonian Lagoon case study. Ocean. Coast. Manag. 101, 14-23. http://dx.doi.org/10.1016/j.ocecoaman.2014. 04.030.

Riedel, R., Schlenk, D., Frank, D., Costa-Pierce, B., 2002. Analyses of organic and inorganic contaminants in Salton Sea fish. Mar. Pollut. Bull. 44 (5), 403-411. http://dx.doi.org/10.1016/S0025-326X(01)00254-5.

Rivera-Guzmán, N., Moreno-Casasola, P., Ibarra-Obando, S., Sosa, V., HerreraSilveira, J., 2014. Long term state of coastal lagoons in Veracruz, Mexico: effects of land use changes in watersheds on seagrasses habitats. Ocean. Coast. Manag. 87, 30-39. http://dx.doi.org/10.1016/j.ocecoaman.2013.10.007.

Ruiz, F., Abad, M., Olías, M., Galán, E., González, I., Aguilá, E., Hamoumi, N., Pulido, I. Cantano, M., 2006. The present environmental scenario of the Nador Lagoon (Morocco). Environ. Res. 102 (2), 215-229. http://dx.doi.org/10.1016/j.envres. 2006.03.001.

Sapozhnikova, Y., Bawardi, O., Schlenk, D., 2004. Pesticides and PCBs in sediments and fish from the Salton sea, California, USA. Chemosphere 55 (6), 797-809. http://dx.doi.org/10.1016/j.chemosphere.2003.12.009.

Salton Sea Authority and Bureau of Reclamation, 1998. Salton Sea Project Work Plan. United States Bureau of Reclamation, Boulder City, NV.

Santos, I.R., Machado, M.I., Niencheski, L.F., Burnett, W., Milani, I.B., Andrade, C., Peterson, R., Chanton, J., Baisch, P., 2008. Major ion chemistry in a freshwater coastal lagoon from Southern Brazil (Mangueira Lagoon): influence of groundwater inputs. Aquat. Geochem. 14 (2), 133-146. http://dx.doi.org/10. 1007/s10498-008-9029-0.

Setmire, J., 1979. Water Quality Conditions in the New River, Imperial County, CA US Geological Survey Water Resources Investigations Report, pp. 79-86.

Setmire, J., Wolfe, J., Stroud, R., 1990. Reconnaissance Investigation of Water Quality, Bottom Sediment and Biota Associated with Irrigation Drainage in the Salton Sea Area, CA, 1986-1987. US Geological Survey Water Resources Investigations Report, pp. 4089-4102.

Suman, D., Guerzoni, S., Molinaroli, E., 2005. Integrated coastal management in the Venice lagoon and its watershed. Hydrobiologia 550 (1), 251-269. http://10 1007/s10750-005-4393-x.

Sutherland, G., Waterhouse, F.L., Smith, J., Saunders, S.C., Paige, K., Malt, J., 2016 Developing a systematic simulation-based approach for selecting indicators in strategic cumulative effects assessments with multiple environmental valued components. Ecol. Indic. 61, 512-525. http://dx.doi.org/10.1016/j.ecolind.2015. 10.004 .

Tavares, D.C., Guadagnin, D.L., de Moura, J.F., Siciliano, S., Merico, A., 2015. Environmental and anthropogenic factors structuring waterbird habitats of tropical coastal lagoons: implications for management. Biol. Conserv. 186, 12-21. http:// dx.doi.org/10.1016/j.biocon.2015.02.027.

Tesfamichael, S.G., Beech, C., 2016. Combining Akaike's Information Criterion and discrete return LiDAR data to estimate structural attributes of savannah woody vegetation. J. Arid Environ. 129, 25-34.

United States Bureau of Reclamation, 1998. Salton Sea Alternatives: Pre appraisal Report. United States Department of Interior, Washington, DC.

Velasco, J., Lloret, J., Millan, A., Marin, A., Barahona, J., Abellan, P., SanchezFernandez, D., 2006. Nutrient and particulate inputs into the Mar Menor lagoon (SE Spain) from an intensive agricultural watershed. Water, Air, Soil Poll. 176, 37-56. http://dx.doi.org/10.1007/s11270-006-2859-8.

Walker, B., Holling, C.S., Carpenter, S.R., Kinzig, A., 2004. Resilience, adaptability and transformability in social-ecological systems. Ecol. Soc. 9 (2), 5.

Yue, W., Liu, Y., Fan, P., 2013. Measuring urban sprawl and its drivers in large Chinese cities: the case of Hangzhou. Land Use Policy 31, 358-370. http://dx.doi. org/10.1016/j.landusepol.2012.07.018. 